disposal of radioactive waste; this problem, which impinges on some of the responsibilities of local authorities, is still under consideration.

One half of the eighty-odd pages of the manual is given to a well-planned supplement which admirably summarizes the essential findings of the International Commission on Radiological Protection (1955) and gives the technical information necessary for implementation of the rules of Parts $A$ and $B$. This section also includes a glossary defining all the technical terms appearing in the manual.

Comparison of the new Code with the older recommendations illustrates the increasingly cautious attitude now taken towards any irradiation of human beings additional to that received from natural sources. The earliest recommendation of a 'tolerance dose' of $1 \mathrm{r}$. per week has been gradually abandoned in favour of a 'maximum permissible dose' of $0.3 \mathrm{r}$. per week, now accompanied by still stricter provisions in terms of maximum cumulative doses for whole-body exposure. The limits applicable for exposure up to thirty years of age and per decade thereafter are equivalent to an average weekly dose of $0.1 \mathrm{r}$. "This is one-third of the maximum permissible weekly dose. In the case of long-term exposure, the protection must be planned accordingly" (Code, p. 52).

On the other hand, less emphasis than formerly is placed upon the necessity for regular blood counts. Provided adequate radiation monitoring is carried out in all circumstances involving occupational exposure, routine blood counts are suggested only in the case of workers who receive average doses exceeding one-half the maximum permissible weekly level averaged over a period of three months, and in the event of a worker acquiring a significant amount of an isotope deposited internally. Presumably the Committee considered that doses of radiation insufficient to affect the blood count could be harmful and that a blood count therefore afforded insufficient security at the lower dose-levels. Even so, the blood count does offer a biological test which cannot be circumvented accidentally or intentionally by anyone, and which can give an indication of high doses which for a number of reasons could be missed by purely physical monitoring.

Hours of work receive no mention in the Code, although the British X-ray and Radium Protection Committee was forthright on this point, recommending a five-day week, "the off-days to be spent as much as possible out-of-doors and not less than four weeks holiday a year, preferably consecutively". No reason is given for this omission in the present Code. It is convenient administratively and it is probably correct to formulate regulations for radiation safety apart from rules about working hours but, in my opinion, it would be unwise to separate these considerations in the case of hospital radiological staff who, in their daily contact with the sick, are exposed to the risk of infection as well as to an agent noted for its toxicity to the blood-forming tissues.

A very great service, however, has been performed by Sir Charles Darwin and his colleagues in producing so useful and valuable a document, which has a field of application much wider than hospital radiological work. The manual must be in the hands of all those who use ionizing radiations in the National Health Service; it should-and almost certainly will-be beside all others who use ionizing radiations for any purpose whatever.

The Minister of Labour and National Service has recently issued a preliminary draft of a new Code of Regulations to safeguard workers employed in industry against the effect of ionizing radiations (Factories (Ionizing Radiations) special Regulations : Preliminary Draft. Pp. 16. H.M. Stationery Office. $9 d$. net). The regulations deal with industrial X-rays and sealed radioactive sources. Draft regulations to deal with unsealed or open sources are in the course of preparation. F. W. SPIERS

\title{
OBITUARIES
}

The Right Hon. Viscount Cherwell, P.C., C.H., F.R.S.

Frederick ALEXaNDER LINDEManN, Viscount Cherwell, was born in Baden-Baden on April 5, 1886, and died in Oxford on July 3, 1957. His father, a naturalized Briton who came from an Alsatian family of French loyalty, was a wealthy engineer; his mother was English. He shared with his father an interest in astronomy and in instrument-making; and physics and mathematics became his principal subjects when he studied at the University of Berlin under Rubens, Planck and Nernst.

His Ph.D. dissertation was completed in 1910 ; it was on the atomic heats of metals at low temperatures, and with Nernst he published some important papers on this subject. Altogether he produced nearly twenty papers before 1915 ; besides the atomic heat work they dealt with subjects as varied as a glass transparent to X-rays ('Lindemann glass'--published jointly with his physicist brother, now Brigadier C. L. Lindemann), astrophysies, and his well-known melt. ing-point formula. The last, which was the subject of his first independent paper, was characteristic: his simple physical model of a crystal lattice melting when its atoms oscillate so violently as to hit their neighbours enabled him to relate, with a minimum of calculation, the melting-point of a material to its Einstein single frequency.

Lindemann's strong loyalty to Britain cut short all this work in 1914, for it took him to the Royal Aircraft Establishment at Farnborough, where he was one of several outstanding physicists who devoted themselves to the many problems arising in the new field of aeronautics. Most of his work was concerned with the instruments of flight; but he is beat known for his diagnosis of the way to recover an aircraft from the hitherto fatal condition of spinning. $\mathrm{He}$ had learnt to $\mathrm{fly}$, and he undertook the trials himself : their success matched his courage, and Lindemann's technique became a standard drill. It has been said that he was not a good pilot, but it should be remembered that there was no obligation whatever for him to fly, and furthermore that he had only one good eye. He doubted the advantages of binocular vision, and would point out that he "had not done too badly" at tennis without it. Indeed, he had won several championships in Germany and 
Sweden before 1914, and competed honourably at Wimbledon after he had become Dr. Lee's professor of experimental philosophy at Oxford in 1919. In that year, incidentally, he published with F. W. Aston a paper on the possibility of separating isotopes which suggested many of the methods afterwards used.

Lindemann's appetite for action outside the purely academic plane may have been so whetted by his Farnborough experiences that he could not again settle into research with his pre-war vigour. In addition, the load of a chair and a department which had been almost moribund for many years may have limited his personal research. His papers appeared less regularly ; the most outstanding were those with G. M. B. Dobson on meteors, with the important and correct conjecture that there was a warm layer in the Earth's outer atmosphere, and that with his father and T. C. Keeley on the instrument now known as the Lindemann electrometer. This originated in the need for a small, sensitive electrometer for use with the photoelectric cells of outstanding sensitivity that had been made under Lindemann's leadership in the Clarendon Laboratory. In the meantime, in one of the heroic ages of physics, the structure of quantum mechanics was being built, and Lindemann's contribution was a book-"The Physical Significance of the Quantum Theory", published in 1932-in which he developed with characteristic ingenuity and insight the applications of the principle of indeterminacy. The book was elegantly and concisely written, and still merits attention.

Lindemann's direction of the Clarendon Laboratory was for some time as diverse as the subjects of his papers; apart from photoelectricity there was no main line of steady research. This was rather hard on new research students, each of whom might have to enter a new field with a minimum of briefing. For the stronger men the system was good: their abilities had already been tested by the unusual and stimulating examinations which Lindemann had set, and their independence of thought and self-reliance were enhanced by their individual researches. If they succeeded, no professor could have been more generous than Lindemann in keeping his name out of their publications. But the result was a series of isolated researches in each of which much effort had to be expended in surmounting the difficulties of entering a new field, and the position of the Clarendon was still scarcely commensurate with its seniority among the world's laboratories. In 1933, however, Lindemann became one of the main sponsors of refuge for the Jewish scientists in Germany. $\mathrm{He}$ had been a constant visitor to the Continent since boyhood, and he appreciated very early the significance of the Nazi movement. Among those to whom he offered refuge was Prof. Franz (later Sir Francis) Simon, and under Simon's leadership the reputation of low-temperature physics at the Clarendon grew rapidly. At the same time, the survivors of the earlier 'sink or swim' phase were producing notable work.

It was not easy to convince Oxford of the needs of physics, or indeed of science in general. Even in 1939 there were only about six fellowships in physics in the whole University. Part of Lindemann's achievement is that he did ultimately succeed in awakening the University to the importance of the subject, with the result that the new Clarendon Laboratory was built and opened in 1939, and new fellowships were created. The new laboratory was the best of its kind in Britain, and fortunately the staff was kept substantially intact throughout the War to work on problems of microwave generation and isotope separation. This enabled the Clarendon to start research again, immediately after the War, with all the apparatus and techniques acquired in the meantime. Lindemann had come to the Clarendon when almost no research was being done; he left it, on voluntary retirement in 1956, a well-equipped laboratory with a great reputation. This end had constantly been before him and, while his way of attaining it had not been entirely the traditional one of personal example and leadership in research, the credit is his.

It is rare, but not unique, for a man of science to be closely associated with a statesman. J. H. Poynting wrote papers of the 'operational research' type at the request of his friend, Joseph Chamberlain. The latter's son, Austen, was among the friends of Lindemann, who had become well known in the 1920 's to several senior members of the Conservative Party. His friendship with Sir Winston Churchill and their collaboration from 1932 onwards is part of our history. Their joint stand with Austen Chamberlain on the scientific possibilities of air defence in 1934 and 1935 was one of the factors which led to our being ready just in time for 1940 . Here again, Lindemann's methods were not those usual to academic mer. An individualist, he unsuccessfully stood for election to Parliament in 1937, while other physicists, with an equal sense of duty, had joined in a committee to help the Air Ministry directly. The happiest verdict on this, at times painful, difference may also be the true one : that the Air Ministry and the country benefited greatly from the committee's work, and from Lindemann's independent approach.

When the Second World War broke out, Mr. Churchill called Lindemann to the Admiralty as his scientific adviser, and when the former became Prime Minister in 1940, the latter moved to the Cabinet Offices ; he was appointed a formal member of the Government as Paymaster-General in 1942. He remained in this post until 1945 , when he returned to Oxford, and he became Paymaster-General again from 1951 until 1953 at Mr. Churchill's request. The flair for simple physical models that was evident in his scientific papers was invaluable in making clear to the Prime Minister in "lucid, homely terms" what the scientific issues were in any problem regarding new weapons. Lindemann's influence on the scientific policy decisions of the War, and from $195 \mathrm{I}$ onwards, was great. He was always prepared to take an unpopular stand, as in 1940 when he refused to believe the accuracy of our bombing claims; his persistent scepticism revealed the facts, and resulted in a complete switch to radio navigational aids to bombing.

By no means all his advice would have been endorsed by other men of science. In particular, he could not resist the very quickness of his mind leading him to form a theory from a minimum of fact; and having once committed himself to the theory, he would be reluctant to accept any subsequent fact that disagreed with it. Moreover, behind a misleadingly aloof exterior he had great warmth of feeling, with strong likes and dislikes, so that his acceptance or contradiction of a particular point of view would sometimes much depend on how he felt towards the 
propounder. These factors-intense loyalty to his theories and his friends-detracted at times from the balance of his judgment; but when this has been admitted, there is much to be grateful for. His criticisms were courageous in expression and stimulating in effect. My own experience is coloured by the memory of his insisting on my being called to give my views on the reality of the $V 2$ rocket threat, to a War Cabinet meeting of 1943 , despite the fact that he knew that I-much his junior and his pupil-was going to differ completely from his own conclusions; and although he was not right about the rocket, it was in part due to his prescience that we were not blind to the parallel threat of the flying bomb.

As a relaxation from the strain of Whitehall during the War, he pursued a long-stending interest in the theory of numbers. In 1933 he had published a very direct and elegant proof of the fundamental theorem of arithmetic, and he now followed this by a heuristic proof of formulæ for the frequency of occurrence of prime-pairs, prime-triplets and other combinations. Unknown to him, these formulre, which he confirmed by counts, had been found by much more elaborate (and equally non-rigorous) methods by Hardy and Littlewood and by Staeckel, but Lindemann's methods were much simpler and more illuminating; no rigorous proof has yet been found.

In the field of nuclear energy, his advice must have been vital. For a long time it was doubtful whether he was convinced that a nuclear bomb was possible. The idea of such destructive power being available to human hands seemed to repel him so much that he could scarcely believe that the universe was constructed in this way ; and it is perhaps against this baskground that some of the war-time decisions about nuclear energy should be construed.

After the War, he keenly supported the setting up of a separate Atomic Energy Authority, and he was a member of the Authority for the last three years of his life. He was also much concerned with general policy in science and technology, and he was intensely anxious to ses both the cultural and material value of science more adequately appreciated in Britain and the status of men of science enhanced. He made speeches of impressive content on all these matters in the Hous $\ni$ of Lords. They sometimes resulted in controversy, but there will surely be universal agreement with this confession of faith which he made in a debate on university education on May 14, 1947 :

"The function of a university teacher, es I see it, is to develop in young people the habits of exact and logical thought, to show them how and where the underlying facts can be ascertained on which conclusions are to be based, to indicate how the great minds of the past have tackled problems, to show what conclusions they have reached and how they have justified them, and, above all, perhaps most important of all, to arouse the students' curiosity and interest and stimulate them to the point of making the students desire to spend laborious days and nights in an effort to contribute themselves something towards the advance of knowledge."

Cherwell had an unusual range of honours. He was elected to the Royal Society in 1920, and he was awarded the Hughes Medal for 1956. He was created Baron Cherwell in 1941, a Privy Councillor in 1943, a Companion of Honour in 1953, and he was raised to a Viscounty in 1956. He received the Messel
Medal of the Society of Chemical Industry, and the LL.D. degree of the University of Aberdeen.

He was not a professional physicist in the sense of having to make his living by physics, since he was wealthy enough by inheritance to have lived in comfort without working. His interest in physics was thus all the purer, and his independence the greater ; at times he accepted no salary for his work for the Government. His will provides for substantial bequests to Christ Church and Wadham College, Oxford, and expresses the wish that these bequests be applied to the foundation of fellowships or studentships for teaching and research in the physical sciences, including astronomy.

Something of his personality will have been evident from this appreciation. His loyalties to Britain and to science transcended all his feelings and permeated the great width of his interests. His wit, his anecdotes, his arguments and his aloofness were the subjects of many 'high-table' stories. His aloofness, however, was easily penetrated by anyone in misfortune; he would go to much trouble to answer a request for help, or to provide help before it had been asked. He placed surpassing value on his friendship with Sir Winston Churchill and on the tenure of his chair; and he faithfully returned to Oxford in 1953 because, he said, the chair was the substance and politics the shadow. The very fact that at critical periods he was in the innermost circles of government and of international relations gave confidence to other men of science that their language and their thoughts would be understood in those circles: and as an ambassador of science when it was first entering directly into the destinies of nations, he commanded the respect and earned the affection of the statesmen with whom he so loyally worked.

R. V. JONES

\section{Dr. Irving Langmuir, For.Mem.R.S.}

In an age of ever-increasing specialization, it is given to few to open up new vistas in many fields and to make notable advances in both academic and industrial worlds. Such a man was Irving Langmuir, whose recent death at the age of seventy-six has left such a gap in the select band of the élite of modern scientists.

Langmuir, who had been a teacher in the small academic Stevens Institute, Hoboken, New Jersey, was invited by Dr. Whitney, director of the Research Laboratory of the General Electric Co., Schenectady, to enter that Laboratory in the summer of 1909 . Instead of being assigned some particular problem, Langmuir was given a free hand in following the various investigations current at that time. He was attracted to the problem of the cause of brittleness in drawn tungsten wire, which Coolidge had then recently developed, and suspected that gaseous impurities occluded in the wire might be the cause. Whitney suggested that he might examine this possibility in more detail, and thus started that series of monumental investigations on the interaction of gases with, and at, the surface of metals, with which the name of Langmuir will always be associated.

Apart from the implication of this work for the problem of heterogeneous catalysis, there emerged, in the form of as it were by-products of his work, fundamental inquiries such as the rigorous computation of the loss of heat from hot filaments, the mer- 